\title{
Cinema e Jornalismo: Boca de Ouro, o filme, e a queda da objetividade jornalística
}

Lisandro Nogueira*

\begin{abstract}
Resumo
Neste texto o autor analisa a forma como jornalistas são representados em filmes brasileiros por meio do estudo de caso do filme Boca de Ouro.

Palavras-chave: cinema brasileiro, jornalistas, represetanção.
\end{abstract}

O cinema brasileiro travou com o teatro um diálogo tímido. $O$ grande momento (1958), de Gianfrancesco Guarnieri, adaptado por Roberto Santos, e Boca de ouro, de Nelson Rodrigues (1962), adaptado por Nelson Pereira dos Santos, são dois exemplos raros do encontro do teatro com o cinema naquele momento. Após Boca de ouro vieram outras adaptações de peças de Nelson Rodrigues para o cinema, principalmente nos anos 70 e 80 . Nelson Rodrigues é uma exceção nesse panorama. As adaptações de seus textos se multiplicaram após o filme de Nelson Pereira.

Na história do jornalismo brasileiro está inscrito um atávico procedimento: alojar as profissões de jornalista e escritor. Nelson Rodrigues encarna com perfeição simbólica esse momento. Em muitas de suas obras, a figura do jornalista aparece com destaque, como em Boca de ouro e Beijo no asfalto - ambas levadas ao cinema por Nelson Pereira e Bruno Barreto, respectivamente. Além dos dramas domésticos e suburbanos, o discurso de Nelson Rodrigues tem também uma inflexão

* Lisandro Nogueira é professor de cinema na Faculdade de Comunicação e Biblioteconomia da UFG.

Comun. Inf., v. 5, n. 1/2, p.77-93, jan./dez. 2002 
corrosiva sobre o mundo do jornalista. À sua morbidez literária, alia-se a prática jornalística e o conhecimento "por dentro" da profissão.

Os americanos criaram os newspaper movies, ou filmes de jornalista, tendo como um dos objetivos representar a profissão e a sucessão de acontecimentos da vida cotidiana que rendem histórias para serem contadas pelas imagens em movimento:

\footnotetext{
Ninguém soube traduzir tão bem o imaginário coletivo que associa a profissão à investigação, à aventura, à independência, ao arrojo, e, igualmente, ao cinismo, à falta de escrúpulos, à arrogância, como o cinema americano. Com sua vocação a heroicização dos personagens, o jornalista encontra terreno fértil para se desenvolver como uma variável dos dois heróis clássicos do cinema americano em que estas características desabrocharam -cowboy e o policial. Nos três, a marca é a atuação individual, entendida como ação de sujeitos em que as qualidades pessoais são ressaltadas. O código que rege a conduta pessoal dos três provém de um senso de justiça e de verdade apurado, bem como em uma noção de oportunidade que orienta as ações e determina os desfechos (BERGER, 2002, p. 17).
}

No Brasil, esse gênero ganha ênfase a partir da filmagem da peça de Nelson Rodrigues, que inaugura a série de filmes que vão mostrar 0 jornalista, seu universo e a trajetória da profissão no processo comunicacional brasileiro. Na década de 50 , Absolutamente certo (1957), de Anselmo Duarte, e O homem do Sputnik (1959) apresentavam jornalistas na narrativa. Mas para os propósitos deste texto, o marco inicial é o filme de Nelson Rodrigues, pela perspectiva da investigação da objetividade jornalística e a nova inserção do jornalista na Comunicação. Após Boca de ouro surgiram, nos anos 60 , filmes como O desafio (1965), Terra em transe (1967) e Brasil Ano 2000 (1969).

Assim como o americano, o cinema brasileiro encanta-se pela figura urbana controvertida do jornalista - um dos símbolos da cidade. Seu papel de "contador de histórias cotidianas", seu convívio com as esferas decisivas do poder e seu crucial acesso a milhões de brasileiros, colocam-no na mira das câmeras, que descobrem um novo personagem. Para o Cinema Novo, no começo dos anos 60 , o jornalista ainda não era um personagem a ser explorado. Era um ponto futuro, um lugar a se chegar e tentar dissecar. Embora quase todos os

Comun. Inf., v. 5, n. 1/2, p.77-93, jan./dez. 2002 
cinemanovistas fossem jornalistas, ou tivessem vínculos com a profissão, mostravam-se preocupados com temas do Brasil rural em filmes que sucederam Boca de ouro: o cangaceiro (Deus e o diabo na terra do sol), os soldados e o povo (Os fuzis), o sertanejo (Vidas secas).

No entanto, a necessidade de um diagnóstico após o golpe de 1964 obriga-os a buscar um personagem urbano que sintetizasse aquele momento. Daí surgem Marcelo (O desafio), Paulo Martins (Terra em transe) e o repórter-fotográfico (Brasil Ano 2000).

Há filmes das décadas anteriores em que aparece o personagem jornalista, porém os newspaper movies brasileiros só ganham relevância a partir de Boca de ouro (1962). Isso se deve, em parte, à emergência da cultura de massa e da crescente urbanização. Nos anos 50, o jornalista já ocupa um lugar de destaque na cidade, porém sua figura ainda é confundida com a do escritor e, mais genericamente, com a do intelectual - no cinema brasileiro, o jornalista começa a ser posto em evidência no decorrer da década de 60 . No cinema americano, o personagem-jornalista aparece nos anos 20:

A personagem emerge no cinema com toda a sua força nos anos 20, quando nas telas os temas populares estão em voga, mas também no mesmo momento em que a vida dos jornais se encontrava intimamente associada à vida da sua comunidade e em que o jornalista partilhava não só a mesma condição social de seus leitores, mas um idêntico universo cultural e simbólico. No entanto, se o cinema mantém o jornalista no rol de suas personagens de predileção mesmo quando esse elo cultural já não tem mais a mesma força, duas ordens de explicação interligadas podem ser invocadas: em primeiro lugar, a formalização a que chegou o filme de jornalista, nos mesmos moldes dos gêneros hollywoodianos; em segundo lugar, a longevidade das próprias formas cinematográficas, em virtude da qual as imagens também têm sua própria história e obedecem a deter minações específicas, num diálogo complexo e enriquecedor com a realidade (SENRA, 1997, p.44)

\section{Cinema e Objetividade}

No Brasil, o Cinema Novo vai impulsionar a discussão sobre o jornalista. Se a maioria dos cineastas é jornalista ou mantém relações próximas com o meio de comunicação, alguns filmes vão espelhar esse profissional concedendo-lhe uma participação importante. No filme de Nelson Pereira, ele não é o protagonista. Embora seja uma figura

Comun. Inf., v. 5, n. 1/2, p.77-93, jan./dez. 2002 


\title{
78
}

importante que contribui para a narração da história, o diretor deixa evidente a importância que Nelson Rodrigues atribui ao jornalista e a seu poder de intervenção, mostrando-o em interação com a cidade, ao percorrê-la atrás da notícia. A cidade aparece nos momentos em que o jornalista está em ação. O espaço do filme concentra-se nas ruas do Rio de Janeiro (centro e subúrbio), nas casas de Guigui (Odete Lara), Boca (Jece Valadão) e na redação do jornal. Os movimentos do jornalista (Caveirinha) ocorrem no espaço da redação, na casa de Guigui e nas ruas. O jornalista é mostrado em plena ação profissional: colhendo a notícia, ampliando as intrigas domésticas, invadindo o espaço privado em busca de uma premiação ("Olha lá que você ainda ganha o prêmio Esso", dizem na redação) e tentando converter toda essa mise-en-scène em objetividade (traduzida como a busca exata da verdade para bem informar o leitor). Esse conceito, básico para o jornalismo, é emblematicamente representado pela noticia, uma forma narrativa que pretende mostrar:

\begin{abstract}
uma realidade objetiva, anterior e independente de qualquer operação racional ou subjetiva e que seria percebida passivamente em sua autenticidade. $\mathrm{O}$ conhecimento encontra-se assim reduzido a elementos de experiência associados e relacionados em percepções que constituem os 'dados' ou 'fatos'. Estes 'fatos', percebidos que são, em sua pureza também podem ser reproduzidos em sua autenticidade por um discurso que opere de acordo com certas regras e procedimentos (PIERRE, 1999, p. 12).
\end{abstract}

O cineasta coloca o jornalista na rua e amplia a extrema ironia do dramaturgo com a profissão e sua pretensão em estabelecer uma verdade que condiz com uma moral. O filme, segundo Xavier (2001, p. 113), abre dois caminhos para que se possa analisá-lo: "pode se privilegiar a articulação do motivo com um conjunto de determinações sociais e históricas, ou compreendê-lo como atualização de um paradigma da condição humana, universal e a-histórica". Na pesquisa optou-se pela determinação social e as conseqüências entre dois campos do conhecimento e das artes: o cinema e o jornalismo. Boca de Ouro também pode ser visto como uma arte de agregação na análise sociológica da arte, de acordo com Candido (1965). É uma arte que procura se incorporar a um sistema simbólico vigente. Isso não implica que ela não possa renovar os códigos ou trabalhar segundo critérios críticos. A nossa opção por Boca de Ouro é pela sua inserção na

Comun. Inf., v. 5, n. 1/2, p.77-93, jan./dez. 2002 
narrativa clássica (arte da agregação) e, ao mesmo tempo, a postura irônica e crítica a modelos e códigos do jornalismo, por exemplo.

Os dois Nelsons fazem um diagnóstico da profissão quando na ação dramática vislumbra-se o conceito-chave do jornalismo americano, totalmente instalado no Brasil. A ironia, contida na peça, é amplamente encampada no filme.

Até os anos 50, não tínhamos a influência maciça da escola americana de jornalismo, que advoga teses opostas às dos europeus. $\mathrm{O}$ jornalismo americano começa a influenciar decisivamente o brasileiro em meados dos anos 50, de forma gradativa, mas com lances ousados. O conceito de objetividade jornalística - que no senso comum significa exatidão e ouvir os dois lados antes de publicar a notíciacomeçava a seduzir, com sua enorme capacidade de aliar o jornalista a um novo padrão de atuação em relação à notícia, ao patrão e às relações com o Estado e a Sociedade. Aos poucos, os "fatos objetivos" passam a pesar na delicada relação com o conceito de "opinião". O modelo de jornalismo baseado na possibilidade da opinião, com um mínimo de identidade, e a não obrigatoriedade a reportar os fatos somente dentro dos inflexíveis limites da objetividade, começa a emitir seus primeiros sinais de fragilidade. A ebulição político-cultural nos anos 60 estanca timidamente esse processo, porém ele alcança seu momento de arranque, para não mais parar, a partir dos anos 70 .

O jornalista é aquele que tem a missão de esclarecer a verdade, de indagar, persuadir e trazer à tona o "que o público quer saber". $\mathrm{O}$ conceito de objetividade enraíza-se como uma das principais pilastras da teoria do jornalismo: Essa noção de verdade permitiu a formulação de alguns prin-
cípios fundamentais da atividade da imprensa: a teoria da
responsabilidade social, baseada na idéia de que o público
tem o "direito de saber", remetendo à classificação idealista
de "quarto poder" - portanto, acima das contradições da
sociedade, sem interesses a defender, capaz de falar em nome
de todos -, e as noções de imparcialidade e objetividade daí
decorrentes. São princípios desenvolvidos no contexto da
sociedade americana, mas cujo reconhecimento transcende
essa particularidade, não só porque vincula-se a postulados
básicos do iluminismo, como porque foram adotados pela
imprensa ocidental em geral, e é em torno deles que se procu-
ra formular uma teoria do jornalismo (MORETZSOHN, 2002,
p. 56 ).

Comun. Inf., v. 5, n. 1/2, p.77-93, jan./dez. 2002 
O conceito contribuiu para efetivar mudanças profundas na maneira de tratar o processo da informação. No jornalismo americano, $o b$ jetividade é sinônimo imediato de verdade, de clareza e transparência. Se na vertente clássica, o cinema formula, praticamente, os mesmos pressupostos para fazer eclodir a ilusão cinematográfica ${ }^{1}$ (a verdade dita por meio do imaginário, mas com intuitos declaradamente pedagógicos), vai encontrar nesse modelo de jornalismo o parceiro ideal. Além do que, os dois são frutos de um mesmo processo histórico e criam dois dos principais personagens da modernidade: o jornalista e o cineasta. No jornalismo clássico, a maneira de relatar uma notícia é semelhante ao narrador da história no cinema: o intuito é sempre o de revelar uma verdade oculta e tornar transparente aquilo que está fora do código:

Tanto no cinema como no jornalismo os dispositivos técnicos e os recursos narrativos ou de linguagem foram desenvolvidos, cada um ao seu modo, a serviço de uma mesma transparência de registro que assegurou, para o jornal, a afirmação de sua objetividade e, para o cinema, a insistência na verossimilhança das suas imagens (SENRA, 1995, p. 88).

Utilizando uma linguagem ilusória, o mecanismo de narração sintetizado por Griffith, ${ }^{2}$ no início do século passado, dá o suporte necessário para um conceito de "verdade", mediante exemplos regeneradores. Ele busca no melodrama um modelo de narrativa propício à coerência e funcionalidade que pretende com os primeiros procedimentos de linguagem cinematográfica. $\mathrm{O}$ modelo de Griffith caminha no sentido oposto ao da tragédia. Esta responsabiliza os homens por suas ações e procura estabelecer os limites do poder humano. Griffith e o seu cinema fincam as bases de um imaginário estético que propõe uma pedagogia moral para a realidade e seu cotidiano. Seu cinema inaugural vai ser atualizado constantemente, acompanhando as inovações tecnológicas e as novas demandas de comportamento e costumes. Há de se ressaltar que o cinema narrativo clássico, após as descobertas de Griffith, ramificou-se em várias correntes. Em termos de conteúdo, as temáticas candentes são incorporadas e o tratamento (a linguagem) vai sofrer, aqui e ali, pequenas absorções de ousadias operadas nos cinemas ditos de "ruptura". Essa operação de absorção de experimentos alheios e discussão de temáticas atuais, junto com a cres-

Comun. Inf., v. 5, n. 1/2, p.77-93, jan./dez. 2002 
cente introdução de tecnologias que ampliam a capacidade da "ilusão cinematográfica", vai fortalecer sobremaneira o cinema clássico e seu público. Apesar da narrativa que quase não ousa em termos de linguagem, as temáticas sempre se sobressaíram nas representações e possibilitaram a edificação de "modelos de cultura":

Fala-se tanto hoje na arte do cinema que podemos estar correndo o risco de esquecer que, em sua maioria, os filmes de que gostamos não são obras de arte. Um filme bom pode nos arrancar de nosso medo surdo e da desesperança que tantas vezes acompanha a entrada num cinema; um filme bom pode nos fazer sentir vivos de novo, em contato, e não simplesmente perdidos numa outra cidade. Os filmes bons nos fazem interessar, voltar a acreditar em possibilidades. Se em algum ponto do mundo de diversão de Hollywood alguém conseguiu inovar com uma coisa que fala a nós, não é tudo corrupção. O filme não precisa ser sensacional; pode ser tolo e vazio, e ainda assim temos o prazer de um bom desempenho, ou apenas de uma boa fala (KAEL, 2000, p. 130).

Pauline Kael se sobressaiu principalmente pelos ataques aos "filmes de arte" e à veneração excessiva de acadêmicos e críticos americanos ao cinema europeu, e a defesa acirrada do cinema narrativo clássico. Andrew Sarris e Dwight Macdonald foram combatidos em várias ocasiões. Não há dúvida sobre a formulação de modelos de cultura advindos desse tipo de narrativa. É bastante óbvio, aliás, que o cinema enseje sempre "modelos de cultura" a partir de sua concepção imaginária enraizada em culturas diversas, e das quais emanam as representações.

Em filmes da narrativa clássica é possível estabelecer modelos de cultura com a sagacidade do diretor em usar recursos da ironia, da sátira e da paródia para burlar mecanismos que tentam trancafiar a narrativa num determinado padrão. Boca de ouro, de Nelson Pereira, e Lúcio Flávio, o passageiro da agonia são dois exemplos conflitantes nesse aspecto. Os filmes que pretendem usar a narrativa clássica e, ao mesmo tempo, discutir problemas políticos e sociais, são exemplos contrários a serem observados. O uso do naturalismo e de gêneros consagrados, como o filme policial, são estratégias que pretendem dar um novo colorido, sem aprofundar nas temáticas, a um tipo de cinema que quer estabelecer uma "verdade" para o espectador:

Comun. Inf., v. 5, n. 1/2, p.77-93, jan./dez. 2002 


\begin{abstract}
Há, nestes filmes, um movimento em direção a um realismo de denúncia: reportar fatos polêmicos da atualidade, testemunhar a experiência histórica a partir da análise de uma resposta individual, a da personagem herói-heroína a uma rede criminosa cuja dimensão é sociopolítica e guarda relação direta com ditaduras focalizadas no momento de sua dissolução. O objetivo é trazer a debate as implicações, para um cinema cujo compromisso é com a verdade, desta adoção das fórmulas de gêneros industriais, particularmente as do thriller policial e as do drama doméstico burguês. Ou seja, que tipo de verdade os filmes tendem a privilegiar quando atrelam o desmascaramento da mentira oficial a tais formulas (XAVIER, 1993, p. 117).
\end{abstract}

Os argumentos são pertinentes, pois as intenções nesses filmes esbarram no tratamento das temáticas e da narrativa. Se as temáticas são atuais e buscam a verdade, assim como no cinema pioneiro de Griffith, acabam edulcorando a realidade e individualizando as soluções. Na vertente do cinema político-clássico que tem a pretensão da justeza e verdade (o exemplo mais emblemático é Costa Gavras) há pouco espaço para nuances e brechas.

Por isso, é importante observar filmes como Boca de ouro. Em filmes de estrutura clássica há contradições, brechas e até o uso da ironia e da sátira em meio a uma narrativa disposta a ousar e tentar desmistificar conceitos como o da objetividade jornalística. É este o caso do filme de Nelson Pereira dos Santos. O jornalista, mesmo empenhando em trabalhar com o fato, a "verdade" do acontecimento, constrói uma ficção, ou uma representação, como se fosse a reprodução do real - real que se quer eivado de verdade e objetividade. No cinema clássico, assim como no jornalismo clássico, submetido aos ditames da objetividade, a busca da transparência (via ilusão) e da verdade (via notícia) é lei:

$\mathrm{O}$ jornalismo viu desde muito cedo no cinema mais que um concorrente (como fez a literatura), um companheiro também dedicado, a seu modo, ao registro fiel da realidade; para o cinema, por sua vez, o jornalismo propiciou a garantia de um registro "objetivo" do mundo visível (SENRA, 1995, p. 88).

\title{
Boca de Ouro
}

Nos newspapers movies, o encontro das duas narrativas realizase geralmente na figura do repórter que corre atrás da notícia objetiva

Comun. Inf., v. 5, n. 1/2, p.77-93, jan./dez. 2002 
e busca um desfecho. Mas Boca de ouro nos engana no que tange à representação do jornalista. É um filme narrativo, no qual o diretor e o autor da peça ironizam a objetividade jornalística. Caveirinha (Enio Santos) é chamado na redação para cobrir a morte do famoso bicheiro. O espaço da redação é ocupado por ele de forma vitoriosa. É cercado pelos colegas que o indicam a um futuro "prêmio Esso" (o mais importante prêmio do jornalismo na época) depois da reportagem sobre o fim do famoso contraventor. Passa por um colega que redige uma notícia soletrando sonoramente o discurso da culpa das instituições pelo caos em que vive o país. Aqui, o jornalista é visto como agente da conflagração e da oposição ferrenha. É uma leve ironia ao atrevimento da profissão e um certo tom esquerdista nas redações.

Nos filmes de jornalista há a tendência para a desaprovação ou consagração do profissional. $\mathrm{O}$ filme prefere a ironia e destoa da referência clássica dos newspapers movies: Jejum de amor (His Girl Friday, 1940), de Howard Hawks. Nele, a profissão é sacralizada. Hildy Johnson (Rosalind Russel) domina o espaço da redação e tornase soberana pela perspicácia. Seu editor é Walter Burns (Cary Grant), parceiro, aliado e mestre. É a apologia da profissão como sinônimo de garra, força de vontade e, sobretudo, vocação - adjetivo que vence todos os óbices e adversidades. Romântico e cômico, Jejum de amor reflete um cisto crônico da profissão: a controvertida profissão eternamente candidata (Senra, 1997), na qual a vocação é atributo fundamental. O jornalismo é uma profissão romântica porque exige vocação, disposição de sacrifício da vida pessoal e configura-se como uma ode à aventura cotidiana atribulada. É uma profissão ambígua em que o amador e o profissional ${ }^{3}$ se misturam. Os newspapers movies americanos celebram em filmes como Jejum de amor esse individualismo e mostram a distância de um ideal da profissão como aquela preocupada com os destinos da sociedade: Hildy só pensa no seu sucesso e, para obtê-lo, não hesita em utilizar qualquer ferramenta, mesmo as mais engenhosas e malvadas.

Caveirinha segue na mesma direção. A câmera passeia rapidamente por esse estereótipo (a vocação e o prêmio pelo esforço pessoal - o Prêmio Esso) e chega ao chefe de redação. A câmera direta sobre sua fisionomia tensa parodia o nervosismo de um ambiente de trabalho. A ordem para Caveirinha é efusiva. As diferenças entre Nelson Pereira e Hawks são sutis no tratamento da vocação e dos desíg- 


\section{4}

nios da profissão. Hildy e Caveirinha saem à rua em busca da notícia. Ao lado dela, existe um editor decidido a estimular seu ego escancarado. A maldade que comete contra um pobre homem: humilhação, manipulação e uso da fonte de forma oportunista e arrogante, tudo isso se torna instrumento para o objetivo despudoradamente pessoal. Ele tem um editor que é mero capataz do dono do jornal. No caso de Hildy, o editor estimula seu individualismo, pois jornalismo, para ele, é "vontade pessoal". Caveirinha é um instrumento para ganhar dinheiro e conquistar prestígio para si mesmo (ganhando o prêmio Esso) e para a empresa.

Os dois filmes trabalham com a noção do jornalismo como terreno de oportunidades e oportunismo. Mas há diferenças: Jejum de amor joga um chantilly nas frestas que poderiam adensar a vilania; romantiza e busca no melodrama o apaziguamento. A construção psicológica dos personagens é conformada no equilíbrio entre as peraltices e as "maldades ingênuas" de Hildy e Burns. Caveirinha (codinome abundantemente sintomático) trafega na narrativa sem romantismo. Seu objetivo, assim como o de Hildy, é pessoal, ou seja, busca de prêmio e satisfação particular. Ele sequer questiona a aprovação do dono do jornal e do editor que decidiu delegar-lhe liberdade plena para usar da psicologia e "vender mais de 10 milhões de exemplares".

Quem manda no jornalismo? Quem decide o que é notícia? A representação da construção em série da notícia é fiel ao que é comum até hoje no jornalismo brasileiro. Conforme o grau de implicação, antes de o jornalista sair à rua ou de o editor finalizar a matéria ou artigo, o proprietário é consultado. Nelson Rodrigues é sarcástico com a profissão e sua infantil ilusão quanto à possibilidade de ter muito poder para decidir qual deve ser a informação importante a ser veiculada. ${ }^{4}$ Após a autorização, por telefone, o editor perpetra uma frase sintomática: "Agora podemos fazer jornalismo de verdade". A "verdade" do jornalismo, nesse caso, já coloca, a priori, a objetividade em plena contradição. Se ela propõe "ouvir os dois lados" ou, no mínimo, ouvir a fonte mais confiável (no caso de Boca de ouro, Guigui é a suposta fonte para a aplicação da objetividade), o desejo e os interesses do dono do jornal serão os instrumentos para direcionar o veredicto da notícia. O editor não exerce plena liberdade de pauta quando se trata de um caso no qual os interesses são superlativos: tráfico de influência, jogo do bicho, dinheiro e violência. Se, em 1962, os interesses da empresa são determinantes, na atualidade a questão continua aberta.

Comun. Inf., v. 5, n. 1/2, p.77-93, jan./dez. 2002 
No filme Doces poderes, de 1996, a editora reporta-se ao mesmo dilema. Ela é obrigada a obedecer a ordens e seu idealismo destoa da realidade da profissão. Num estudo sobre o telejornalismo, Pereira Jr. abordou o problema:

A preocupação em terminar apressadamente uma matéria na
hora do fechamento, como acontece com os editores de texto
do RJTV1, [telejornal regional da TV Globo] acreditamos es-
teja associada aos perigos que cada matéria traz para a reda-
ção e para a organização jornalística. É que cada notícia afeta
potencialmente a capacidade dos jornalistas no desempenho
da sua atividade diária, atinge também sua competência pro-
fissional diante dos superiores e tem influência ainda nos
lucros da empresa (Pereira Jr., 2001, p. 120).

O pesquisador afirma que os jornalistas só têm uma arma contra a pressão diária na tomada de decisões: a objetividade. Ela é o antídoto que o jornalista tem para se proteger: "Os procedimentos adotados pelos jornalistas para se defenderem dessa pressão constante podem estar relacionados com um dos mitos da atividade jornalística: a objetividade". Com ela, o jornalista defende-se do tempo, do patrão e das vicissitudes diárias da redação:

O jornalista, ao pautar um tema, ao escrever uma matéria, ao fazer uma entrevista, age, antes de tudo, para cumprir uma rotina profissional cuja especificidade é, sem dúvida, a celeridade dos prazos. Mas age também em função da lógica das relações sociais do universo em que interage, ou seja, em função do conhecimento e do reconhecimento de si próprio, de seu nome. Obviamente, cada jornalista, dentro de sua empresa, terá maior ou menor grau de independência, em função de vários fatores: segurança em relação ao seu emprego, que por sua vez dependerá da posição já ocupada dentro da empresa, de seu prestígio dentro do campo jornalístico (como editorialista, colunista, produtor autônomo de informação, etc) e do grau de concentração da mídia em geral (BARROS FILHO, 1995, p. 106).

Com o beneplácito do dono da empresa, o editor encaminha a pauta da reportagem para Caveirinha, assegurando para o jornalismo uma nova ferramenta: a psicologia. Colher a notícia não é uma tarefa fácil, pois exige domínio da linguagem, presença no contexto social e uma boa capacidade de persuasão. Boca morreu e chega a hora de

Comun. Inf., v. 5, n. 1/2, p.77-93, jan./dez. 2002 
ouvir sua ex-amante, moradora do subúrbio. Ela sabe quase tudo do bicheiro. Saberemos da vida dele pelas três versões diferentes que Guigui vai contar. Caveirinha vale-se de todas as artimanhas para conseguir a informação. Assim como Hildy faz com o prisioneiro, ele seduz Guigui pela escuta psicológica atenta e envolvente. Quer saber dos crimes, do ambiente hostil, das tramas e conquistas de Boca de Ouro. Envolve Guigui, antecipando aquilo que hoje fazem as televisões, em alguns telejornais e programas de auditório, ao seduzir os entrevistados, dando-lhes a rara chance de aparecer na telinha. Para isso, faz fotos da ex-amante de Boca e promete a exposição na mídia. O jogo é envolvente pela ânsia da informação perpetrada por Caveirinha e a formidável performance de Guigui ao contar três versões diferentes para o mesmo episódio. As versões tratam da vida íntima de Boca com um casal: Leleco (Daniel Filho) e Celeste. Guigui é a amante que conta a história de traição, sedução, chantagem e morte, envolvendo os três durante o tempo em que morou na mansão do bicheiro. $\mathrm{O}$ embate entre os dois é uma demonstração da astúcia do entrevistado e das artimanhas do entrevistador. A construção das três versões depura a trajetória da ex-amante. Com os relatos (verdadeiros ou falsos?), ela refaz sua trajetória de vida, reconcilia-se com o marido e coloca Caveirinha (a imprensa e sua objetividade) numa situação inusitada. Seu relato, crê o jornalista, tem um pressuposto de verdade, posto que privou de sua intimidade, e a vida privada é quase sempre o lugar de revelação e reparo do erro. Ela volta para o lar, o marido e as filhas. Há ressentimento, mas, ao contar as três versões, ocorre um ajuste de contas e sua fala lhe revela outro destino. É na vida doméstica, cercada pela compaixão da unidade familiar, que acontece a reconciliação com a natureza humana. No fundo, o homem é dócil e bondoso. $\mathrm{O}$ que o torna violento é o espaço público e seus vícios embutidos.

No espaço privado o herói recupera sua natureza bondosa. Guigui, a heroína, recebe o jornalista em sua casa, com as filhas e o marido em volta. O repórter não a convida para um encontro na redação ou em outro espaço público. É na casa, no ambiente familiar, que pensa recuperar a verdade sobre Boca de Ouro, por meio da fala sincera da suburbana.

O espaço do subúrbio é sempre acolhedor para com a imprensa, principalmente de televisão. O público sabe do poder da mídia na correlação de forças com o Estado. É uma relação delicada, que pressupõe uma troca e, em vários casos, envolve submissão, passividade e

Comun. Inf., v. 5, n. 1/2, p.77-93, jan./dez. 2002 
também reação. A força do jornalismo, ${ }^{5}$ em parte, advém do imaginário criado em torno dele: seus jornalistas famosos, a parafernália técnica e a presença mágica da câmera, seja de fotografia, televisão ou cinema.

Com toda essa carga simbólica e o poderio junto ao aparelho de Estado (o uso do espaço da mídia como arma para interpor, reivindicar e pressionar em favor de demandas monumentais), o subúrbio tende a atender as solicitações dos jornalistas. Lins e Silva (1985) realizou estudo sobre o Jornal Nacional, da TV Globo, baseado na teoria da recepção, no qual rechaça a idéia de que os meios de comunicação manipulam a informação e agem sobre a passividade do telespectador. Essa teoria veio aprimorar a pesquisa sobre a relação dos meios e as mensagens com o público. Em Borelli e Lopes (2002), a telenovela é vista sob esse ângulo e revela outros parâmetros para a análise dos efeitos dos meios sobre a população. A pesquisa revela como as pessoas recebem as ficções seriadas. No caso do jornalismo aqui em questão há um encontro real entre esses profissionais e a população. $\mathrm{O}$ jornalista tem um acesso físico aos moradores e as possibilidades de manipulação podem ocorrer quando o encontro acontece no cotidiano: a força caminha para quem detém o aparato simbólico e seus instrumentos.

É uma disponibilidade considerável porque é a instituição que ainda se lembra dos problemas de gente que mora distante e não tem fóruns para se manifestar. É comum o jornalismo usar os recursos fáceis do sentimentalismo e mergulhar toda uma família num mar de lágrimas, com oálibi escuso de levantar a "verdade" sobre um acontecimento lamentável e violento. Mas o jornalismo de televisão e o jornalismo impresso popularesco aprenderam com o cinema clássico as técnicas dramáticas que conduzem o relato para um certo sentimentalismo. E, ao ouvir os relatos, conclui que realiza um jornalismo pautado pela objetividade, ou seja, a emoção dá o aval de veracidade porque quem "chora não mente" - ainda mais se chorar no espaço privado, dentro ou na porta da casa.

No filme, a opção de Nelson Pereira caminha ao lado de Guigui, em oposição à avidez da imprensa. No campo psicológico, as histórias contadas por ela reconstroem sua vida e ludibriam a pretensa objetividade. Para minar a objetividade perseguida por Caveirinha, Guigui perfaz um percurso de depuração do ressentimento. Amante de Boca e testemunha das suas maledicências e amores fortuitos e brutais, ela

Comun. Inf., v. 5, n. 1/2, p.77-93, jan./dez. 2002 
faz da sua fala o caminho para a libertação. Suburbana e celebridade por um instante, aproveita-se para fazer sua "terapia", usando um jornalista como suposto ouvinte qualificado. Caveirinha sai da redação com o mote de que deve usar a psicologia para arrancar tudo que ela sabe sobre o contraventor. Sua escuta é, em principio, privilegiada porque a população escuda-se na imprensa para fazer dela seu divã, ou seja, abre o "inconsciente" incondicionalmente, numa transferência de responsabilidades que não encontra amparo na maioria das vezes. Isso porque a escuta de Caveirinha é interesseira e seu real objetivo é muito evidente. A fala de Guigui é apenas estratégia para a aplicação de uma objetividade. O que emerge da sua fala, entretanto, endossa o humor e a revitalização da protagonista. Sua subjetividade emerge e seu ressentimento é escoado na reconstituição da história pregressa. A objetividade jornalística não encontra apoio na fala enviesada de Guigui. A cada momento ela conta uma história em que a superação do ressentimento aplaca qualquer tentativa de reprodução das coisas assim "como elas aconteceram".

No campo cinematográfico, o ressentimento é uma das principais molas propulsoras das personagens vitimizadas. Num primeiro momento, o ressentimento tem o poder de provocar grande empatia e adesão. (Kehl, 2000) assinala que "o ressentimento é uma conseqüência bastante previsível da recusa do sujeito em implicar-se no próprio desejo. Ressentir-se, ou como a própria palavra indica, insistir repetidamente na atualização de um sentimento, é sempre se ressentir contra o outro". O indivíduo passa a vida lamentando o que fizeram com ele sem assumir sua própria condição e desejo. No cinema, a identificação com o personagem vitimizado e ressentido é freqüente:

Na dramaturgia o poder identificatório do ressentimento reside na esperança que ele oferece ao espectador de que o outro possa ser responsabilizado pelas conseqüências dos atos e decisões do sujeito $\mathrm{A}$ adesão ao ressentido também pode ser movida pela má consciência do neurótico - "se ele se queixa, eu devo ter feito alguma coisa errada..." - mas baseia-se principalmente na aposta de que haja algo a ser cobrado, dos outros ou do outro, pelas consequiências de nossas escolhas. Seu poder em fazer funcionar o cinema, sobretudo os filmes ditos de ação, reside no mesmo ponto. São os personagens vitimados e/ou vingativos que conduzem o fio narrativo, ainda quando sua ação é praticamente a reiteração de

Comun. Inf., v. 5, n. 1/2, p.77-93, jan./dez. 2002 
uma imobilidade e promovem no espectador o gozo vicário de poder, ao mesmo tempo, agir em nome próprio e alegar uma certa irresponsabilidade, uma (ilusória) inocência em relação ao desejo (KEHL, 2000, p. 217).

Guigui, em uma das versões, destila ressentimento por Boca não ter valorizado sua companhia e cumplicidade. Ela largou o marido e as filhas para permanecer ao lado de um homem carente de identidade afinal, "eu sou o que os jornais dizem", como pronuncia Boca. Ou, como afirma Xavier (2001, p.28), ele será para "nós o que Guigui disser nas três versões". A fala de Boca é feita de clichês e a superação do trauma, por ter nascido na pia de uma gafieira, é feita pela busca insaciável de poder, que só alcança o ressentimento e a violência. Com sua fala subjetiva, ela destitui o querer objetivo ${ }^{6}$ de Caveirinha e instala nele a frustração. Ele a engana o tempo todo sem informar da morte de Boca. Quando Guigui fica sabendo, ela conta a última versão: o bicheiro foi morto por uma grã-fina da zona sul, Maria Luíza. Na última tentativa, a caminho do necrotério, para usar o testemunho e salvar a reportagem, ele consegue a reconciliação dela com o marido. Pensa em usar Guigui para uma cobertura sensacionalista. O desfecho é consagrador para a suburbana que ilude Caveirinha e repele o uso de sua imagem. A cena de Guigui e o marido correndo do repórter pelo centro do Rio de Janeiro é simbólica de uma recusa ao espetáculo e à "celebrização por instantes". Os dois Nelsons, na peça e no filme, colocam o jornalismo em xeque e desmontam o discurso da objetividade. Ela não quer o sucesso pelo brilho rápido proporcionado pelo jornal de Caveirinha. Seu ressentimento, evidenciado na versão em que cobra o amparo de Boca, foi superado na exaltação da subjetividade.

\footnotetext{
Abstract

In this text the author analyses the way journalists are represented in the Brazilian cinema, through the case-study of the movie Boca de Ouro.

Keywords: Brazilian cinema, newspaper movies, representation.

\section{Notas}

1. O criador da linguagem narrativa clássica (os filmes de começo, meio e fim), D.W. Griffith, a partir dos anos 10 do século XX, elaborou, por meio de
}

Comun. Inf., v. 5, n. 1/2, p.77-93, jan./dez. 2002 
inúmeros filmes, uma noção de verdade moral, tendo o cinema como suporte de comunicação. Com sua habilidade e intuição, Griffith viu ser possível realizar mensagens morais utilizando o imaginário cinematográfico: deu movimento à câmera, que até então era fixa, dividiu as cenas para possibilitar as ações paralelas e dar a ilusão de que aconteciam ao mesmo tempo, descobriu o close e deu a ele status privilegiado na ação dramática. Sobre Griffith ver Xavier (1984) e Sklar(1975).

2. Griffith realizou inúmeros filmes curtos e dois longas-metragens considerados referência na história do cinema: Intolerância e $O$ nascimento de uma nação. Sua grande contribuição foi sintetizar procedimentos embrionários da linguagem cinematográfica, além de adaptar o teatro e a literatura melodramática do século XIX para a narrativa das imagens em movimento. Tudo isso servia para disseminar a mensagem moral protestante que misturava o cineasta com o evangelista: "Na aventura da origem, Griffith é uma boa trilha. Ao percorrê-la, é difícil separar o artista do pregador; o filme que inova, do sermão protestante; o desempenho admirável da mensagem cujos preconceitos às vezes passam da conta, mesmo considerando o contexto em que se inserem" (Xavier, 1984, p.11).

3. Sobre o profissionalismo no jornalismo e sua relação com a objetividade, ver Hallin (1996), que credita à nova racionalidade administrativa o afastamento da profissão do partidarismo, sob a luz da Teoria da Responsabilidade Social. Moretzsohn (2002) observa que "defender a objetividade e o profissionalismo seria uma forma de reagir aos interesses comerciais que cada vez mais se impõem". Sobre a aliança entre profissionalismo e objetividade, ver também Barros Filho (1995).

4. Um dos debates mais intensos na comunicação atualmente é saber qual instância (mercado ou jornalistas) "dita as leis e os critérios na produção e difusão da informação jornalística" (Sousa, 2002). Discussão complexa, interpretada pela teoria construcionista do jornalismo como uma ação resultante da interação de vários processos. Sousa (2002) argumenta que, nessa perspectiva "não determinística, os jornalistas são vistos como agentes possuidores de um certo grau de autonomia na ação, especialmente face ao poder econômico e político".

5. O cineasta Eduardo Coutinho, realizador dos documentários Cabra marcado para morrer (1964), Santo Forte (1999) e Edifício Máster (2002), além do trabalho de meia década (anos 70) no Globo Repórter, da Rede Globo de Televisão, avalia que o telejornalismo "viciou" a população a ter um discurso pronto quando das entrevistas, seja ao vivo ou não. Segundo ele, o público se acostumou tanto com a linguagem do telejornalismo que "decorou" o código, e os editores produzem como se já conhecessem $a$ priori o mundo das pessoas.

6. Silva (1997) sintetiza as regras mais usadas para alcançar a objetividade, mesmo que, segundo ele, elas sirvam mais para evitar atritos com leitores e empresa: "1. Procurar citar a fonte das informações, e como a credibilidade do fato tem muito a ver com quem relata o fato, aumenta o grau de aceitação; 2 . Ouvir o outro lado da história é outra regra para tentar obter mais de uma

Comun. Inf., v. 5, n. 1/2, p.77-93, jan./dez. 2002 
versão, mesmo que não se chegue a nenhuma certeza; 3 . Ceder espaço igual para posições conflitantes; 4 . Dar acesso igual para todos os segmentos da sociedade".

\section{Referências}

BERGER, Christa. Jornalismo no cinema. Porto Alegre: UFRGS, 2002.

SENRA, Stela. O último jornalista. São Paulo: Estação Liberdade, 1997.

PIERRE, Francisco Eduardo. A hegemonia do modelo objetivo e a formação do jornalista. Comunicação \& Informação, Goiânia, v. 2, n. 1 Jan./Jun. 1999.

XAVIER, Ismail. Melodrama ou a sedução da moral negociada. Novos Estudos Cebrap, São Paulo, n. 57, jul. 2000.

XAVIER, Ismail. A força e os limites da matriz melodramática. Revista USP, São Paulo, n.19, 1993.

CANDIDO, Antonio. Literatura e Sociedade. São Paulo: T. Queiroz, 1965.

KAEL, Pauline. Criando Kane. Rio de Janeiro: Record, 2000.

BARROS FILHO, Clóvis de. Ética na comunicação. São Paulo: Moderna, 1995.

SOUSA, Jorge Pedro. Teorias da notícia e do jornalismo. Florianópolis: Argos, 2002.

PEREIRA JR. Alfredo Eurico Vizeu. Decidindo o que é notícia. Porto Alegre: Edipucrs, 2001.

SILVA, Carlos Eduardo Lins da. Muito além do Jardim Botânico. São Paulo: Summus, 1988.

KEHL, Maria Rita. Desejo e liberdade: a estética do ressentimento. In: BARTUCCI, Giovana (Org.). Psicanálise e cinema. São Paulo: Imago, 2000.

SILVA, Marconi Oliveira da. O mundo dos fatos e a estrutura da linguagem. Porto Alegre: Edipucrs, 1997.

Comun. Inf., v. 5, n. 1/2, p.77-93, jan./dez. 2002 